\title{
On the history of health care in Turkestan and the Caucasus: episodes from Doctor Zeynab Tambiyeva's biography
}

\author{
Takhuz Z. Akhmadov', Madrim Makhmudov² \\ 1 The Chechen State University \\ 32 Sheripova St., Grozny 364024, Russia \\ 2 Urgench branch of Tashkent Medical Academy \\ 28 Al-Horazmiy St., Ugrench 220100, Uzbekistan \\ Corresponding author: Takhuz Z. Akhmadov (t.ahmadov@mail.ru)
}

\author{
Received: 17 November 2017 Accepted: 23 November 2018 Published online: 31 December 2018
}

Citation: Akhmadov TZ, Makhmudov M (2018) On the history of health care in Turkestan and the Caucasus: episodes from Doctor Zeynab Tambiyeva's biography. History of Medicine 5(4): 286-291. https://doi.org/10.3897/hmj.5.4.35689

\begin{abstract}
Based on the analysis of available publications and using archival materials, an attempt has been made to present the main periods in the life and work of Z.S. Tambiyeva, one of the first women to work as a doctor in the national regions of the Russian Empire. Specificities inherent to the provision of medical care for the peoples of the Muslim regions and important moments in the rural doctor's work are considered.

A female doctor's role in providing medical assistance to the local population has been noted, since in the regions where Muslims lived, women, due to local customs and religious traditions, did not seek medical help from male doctors. In December 1911, Z.S. Tambiyeva moved to the Baku Governorate. From 1912, she worked as a private practicing doctor in the industrial village of Raman, in the suburbs of Baku. In 1917-1920, she worked at the Kabardin Public Hospital in Nalchik, in which, from 1914, a military hospital was opened for wounded and sick soldiers and officers who participated in World War I. She was the head of the women's department of the district (regional) hospital in 1920-1923. Later she lived in Baku, and as the wife of an "enemy of the people", she did not have a permanent job for a long time. She became a gynecologist in a city clinic in 1936.
\end{abstract}

\section{Keywords}

health care history, female doctor, Tambiyeva Z.S., medical care, health care of Turkestan, health care of Azerbaijan, health care of Kabardino-Balkaria

In the history of health care in Central Asia, Azerbaijan and Kabardino-Balkaria, a still little-studied issue is the activity of one of the first women doctors of the "Mohammedan religion", Zeynab Sadykovna Tambiyeva (Fig. 1).

The question of her ethnicity remains debatable. In the collective monograph "The History of the Peoples of the North Caucasus (late 18th century to 1917)" (1988), she is listed among the first doctors from among the local population of Kabardino-Balkaria (Istoriya narodov Severnogo Kavkaza... 1988). Some researchers believe Z.S. Tambiyeva was the first from among the mountain women of the North Caucasus to receive a higher medical education (Psikhomakhova 2013, Mutieva 2016) others consider her the first from among Muslim women of Kabardino-Balkaria (Maslov et al. 2005, p. 36). Due to the lack of archival materials for that period, one of the authors of this research considers Z.S. Tambiyeva to be a member of the Balkar people (Akhmadov 2014, p. 509), while another author considers her to have been Kazakh (Makhmudov 1988). There is an opinion that she was Azerbaijani (on the Baku community's Parapet and Bizimkilar forums). The life of the "wife of the enemy of the people" remains virtually unexplored after the arrest of her husband in 1927. This, and in-depth research data that we have recently acquired, prompted us, representatives from the fields of medicine and history, to turn our attention to this issue again.

Zeynab Sadykovna Tambiyeva (née Abdrakhmanova) was born in Tashkent on November 20, 1881, to a noble family whose representatives were Tatars in government 


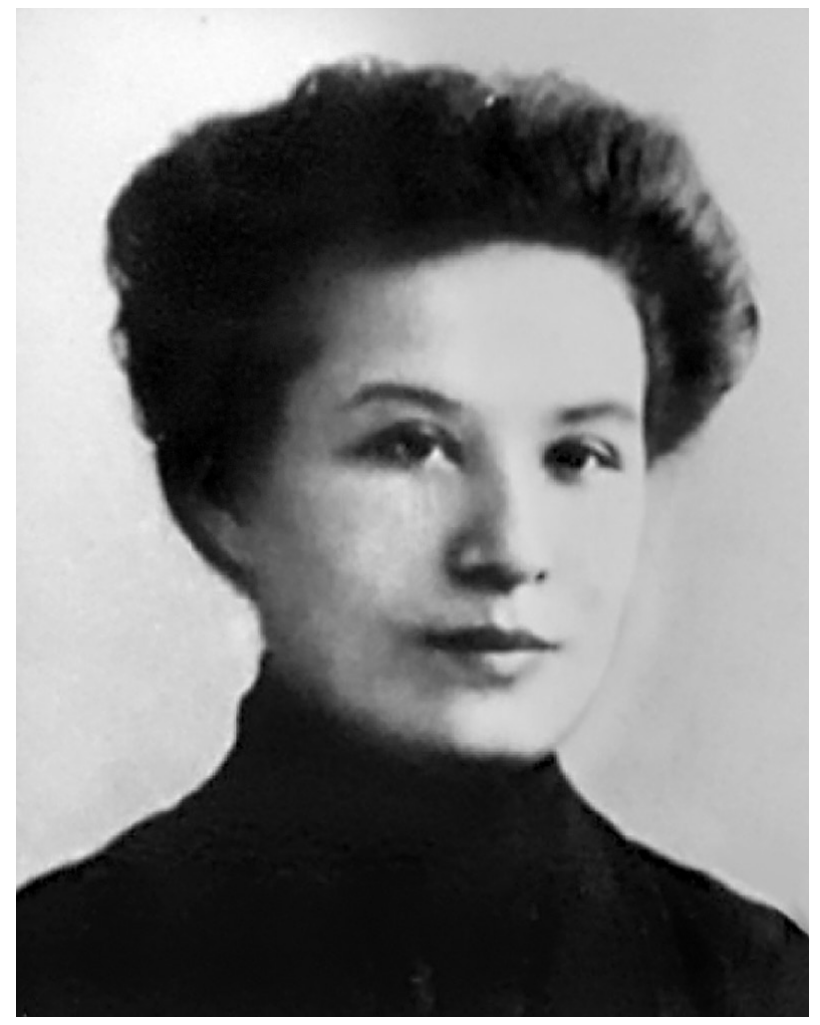

Fig. 1. Z.S. Tambiyeva (1908).

From the photo library of the Archive Service of the KabardinoBalkarian Republic.

service (her father was a Kazan Tatar and her mother was from the renowned Yenikeyev Tatar family).

In the Russian Empire, there was a special "institute of serving Tatars" whose duty was to provide military service and defend the Russian state (Gabdullin 2006). From the outset of the colonization of Turkestan, serving Tatars arrived in the region with Russian troops (soldiers and officers, translators, teachers, religious figures, traders) (Shigabdinov and Zhukova 2002). In the second half of the 19th century, a Tatar settlement appeared in Tashkent. The Tatar population lived there (mainly the trading class): there were cathedral mosques, educational institutions, including Tatar ones (Vasilyev 1891).

In August 1891, after an exam, 9-year-old Zaynab was admitted to the preparatory class at the Tashkent Women's Gymnasium, and in 1899, as indicated ${ }^{1}$ on her diploma "Bibi-Zaynab Sadykovna Abdrakhmanova [...] the daughter of a retired lieutenant colonel of Mohammedan religion, 17 years old"2, graduated with honors from the full study course (Fig. 2).

\footnotetext{
Personal archive of Saadat Pagovna Tambiyeva, the daughter of Z.S. Tambiyeva. Materials provided by descendants of the Tambiyevs - A.K. Shaparova and A.V. Davidovich

2 "Bibi" is the most common prefix for female names among the peoples of Central Asia. The name-forming component serves as a determinant of female names, meaning "Mrs." or "Lady."
}

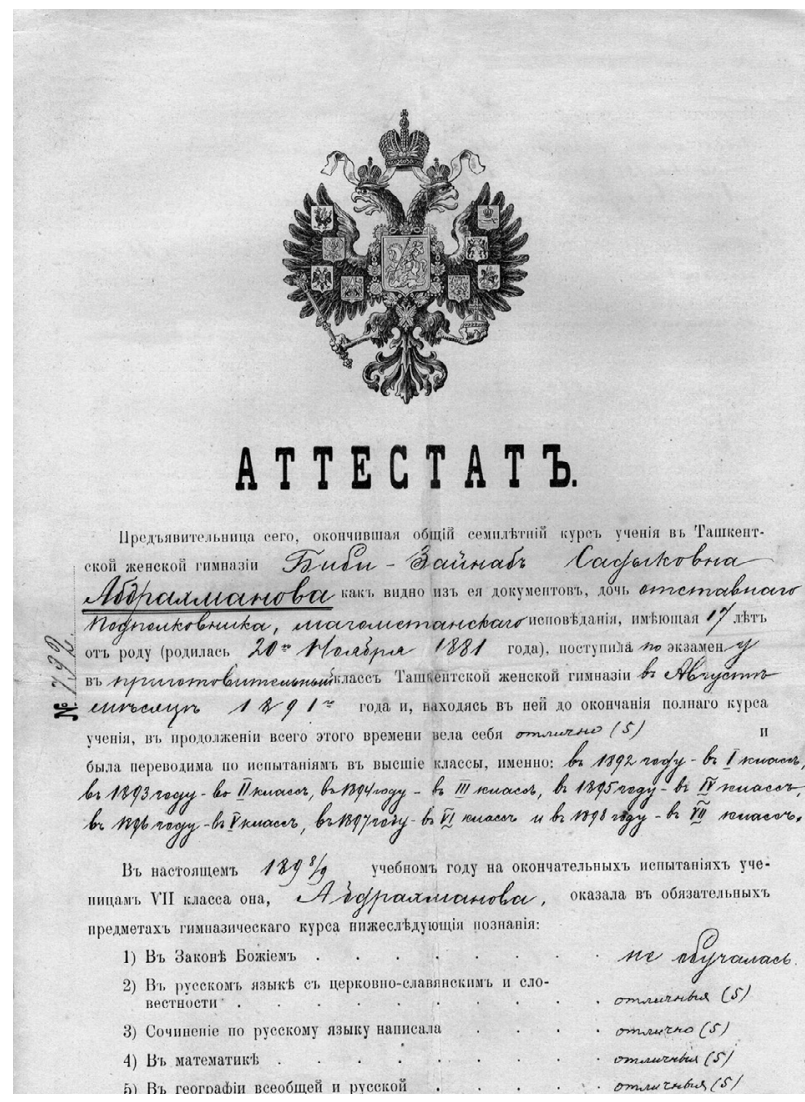

Fig. 2. Fragment of the diploma of Z.S. Tambiyeva (Abdrakhmanova). ${ }^{3}$

From the archive of S.P. Tambiyeva. ${ }^{4}$

Tambiyeva's desire to gain a higher medical education was fraught with serious difficulties, especially on the outskirts of the nation. According to the university

\section{Text on the picture:}

DIPLOMA

The bearer of this document, the graduate of the general sevenyear course of study at the Tashkent Women's Gymnasium, Bibi Zaynab Sadykovna Abdrakhmanova - as recorded in her documents, daughter of a retired lieutenant colonel and of Mohammedan confession -17 years of age (born November 20, 1881), enrolled in the preparatory class at the Tashkent Women's Gymnasium after examinations in August of 1891 and, enrolled there until the end of the full course of study, with continuous excellent results (A's), passed higher classes, namely Class I in 1892, Class II in 1893, Class III in 1894, Class IV in 1895, Class V in 1896 , Class VI in 1897, Class VII in 1898.

In the present 1898/1899 academic year, she, Abdrakhmanova, in taking the final subjects of the gymnasium course, received the following results in the final subjects of the seventh grade:

1) Scripture knowledge - not studied

2) Russian language with Church Slavonic - Excellent (A)

3) Written Russian language essays - Excellent (A)

4) Math - Excellent (A)

5) General and Russian geography - Excellent (A)

4 Courtesy of A.K. Shaparova and A.V. Davidovich - descendants of the Tambiyevs. 
regulations of 1863 , women could not study in higher educational institutions. The first female Russian doctors received their education abroad.

There was a negative attitude towards women who wanted to get a higher education: they were sneeringly referred to as "short-haired girls". ${ }^{5}$ Under pressure from the public, in the 1870s women's higher education medical courses (from 1872) and women's medical institutes (from 1897) began to open in Russia.

The training of female doctors was very important, however, especially among Muslim women. In the Muslim-populated regions, women, due to traditions (including religious ones), almost never sought medical help from male doctors, which led to tragic consequences. In this regard, in order to improve public health and medical care for women and indigenous children, the Council of the Turkestan Governor-General decided to allocate 10 study scholarships for Turkestan girls at the Saint Petersburg Women's Medical Institute (Makhmudov 2015, p. 176). One of these 10 scholarship holders was Bibi-Zeynab. In 1903, she enrolled in the Women's Medical Institute in Saint Petersburg. The institute was opened with donations in September 1897. Its clinical base was located at the Petropavlovsk Hospital. It was the first educational institution in Russia where women could receive a medical higher education. According to the new Regulation on the Saint Petersburg Women's Medical Institute (May 1904), its training was equivalent to universities' medical faculties, the students were transferred to state support, and graduates received the title of doctor and the right to a degree (i.e., female doctors received the same rights as male doctors).

Following successful studies at the institute, Bibi-Zeynab Sadykovna Abdrakhmanova was awarded the title of doctor with honors, with full rights and benefits, at a May 21, 1908 meeting of the Medical Testing Commission. In October 1908 she received a diploma. ${ }^{6}$

At the end of the school year, in April 1908, Zeynab appealed to the Turkestan District Military Medical Inspector with a request to appoint her as a local doctor in the Khan-Abad village in Tashkent county. ${ }^{7}$

A medical point was created there in 1899 by the military doctor M.V. Drozdov. As per the decision of the Main Military Medical Directorate of the Military

\footnotetext{
In this respect, an excerpt from the novel "Crime and Punishment" by F.M. Dostoevsky is illustrative: one of the characters, an assistant to noncommissioned warden Ilya Petrovich (nicknamed "Gunpowder"), says: "Furthermore these midwives are too common...” I'm talking about these short-haired girls... I myself called them midwives and I find that the nickname is completely satisfactory. He-he! They find their way into the academy, learn anatomy; Well, tell me, I'm sick, well, shall I call a girl to treat me? He-he!"

6 A document from the personal archive of S.P. Tambiyeva.

7 Russian State Military Historical Archive. A. 546. S. 2. F. 3696. P. 26.
}

Ministry, Doctor Z.S. Abdrakhmanova was appointed to the civil service as a local doctor of the KhanAbad rural-medical district of the Tashkent county of the Syr-Darinskaya district in the Turkestan region (Zhynisbaev 2014, Rossiyskiy meditsinskiy spisok... 1909). The civil service guaranteed a high monthly base salary, additional monetary allowances, paid annual leave and an old-age pension.

According to the Medical Charter (1905), in the Syr-Darinskaya district of the Turkestan region, the rural-medical department consisted of a local doctor, a medical assistant and midwives. ${ }^{8}$ The district doctor was in charge of the region's six-bed hospital, and the doctor's duties included providing medical assistance to the population within the region and directing and teaching local students. On average, each medical district in the region covered 24,000 square versts with a population of 84,000 people (Obzor Syr-Darinskoy oblasti... 1912). The clinics were located in private homes that did not meet sanitary requirements.

Medical personnel had to work in the most difficult of conditions, in the absence of transport links and under an enormous workload, with the population's high mortality rate (especially among children), and the significant incidence of infectious and skin diseases in the region as well as the so-called social diseases.

In their practical work, they paid attention to cultural and educational tasks and sought to improve the living conditions of the rural population, the poor and illiterate.

After working two years in Xonobod (Khanabad), Z.S. Tambiyeva became a district doctor in July 1910 in the Kurgan-Tyub settlement in Andijan district, Fergana region, located near the city of Osh (Rossiyskiy meditsinskiy spisok... 1911). At her new location, she faced similar difficulties working as a rural doctor, which was complicated not only by the population's traditional distrust of a female doctor, but also the mistrust of her male colleagues.

Turkestan history expert A.I. Dobrosmyslov noted the special importance of female doctors for "public health": "The first female doctors' hard work and careful and cautious attitude to work brought the matter of presenting assistance to the native women and children to the forefront. And the work was considerable, overcoming inertia and other conditions" (Dobrosmyslov 1912, p. 332).

Z.S. Tambiyeva provided a wide range of medical care; she was engaged in sanitary and educational work and promoted the knowledge of hygiene. Very soon she gained authority among the local population. In one of her letters to her future husband, she expressed doubts about whether she would be able to

\footnotetext{
8 The code of laws of the Russian Empire. Volume XIII, book 5. Saint Petersburg, 2012. P. 233-235.
} 
devote herself to the people's service and whether the people's prejudices would hinder her. In the letter of reply there were such lines as: "Your question ... my friend ... strengthened my faith in general that we can serve in union not only for ourselves, but also for our close brotherhood! Not only will I not prevent you from working for the people, but I dreamed about this in the silence of my soul, and I thought to send you on this path step by step".${ }^{9} \mathrm{He}$ assured her that he would be her faithful companion in the work for "the benefit of the suffering people ...A woman is an equal member of society ... She has to independently decide on her social and family status."

In December 1911, Zeynab married and moved to the Baku Governorate, where from 1912 she began working as a private practicing physician in the industrial village of Ramana (in the suburbs of Baku) (Dopolnenie k Rossiyskomu... 1915).

After the February Revolution, in the spring of 1917, the Tambiyevs moved to the settlement of Nalchik in the Terek region. Z.S. Tambiyev together with wellknown Kabardian doctors B.M. Shogenov (18751928) and I.M. Shakov (1878-1941) (Akhmadov 2014, p. 507-509) began to work in the Kabardian public hospital where, from 1914, a military hospital was opened for wounded and sick soldiers and officers who participated in World War I (1914-1918) (Akhmadov 2014, Nakhushev 1967).

Nalchik was not a resort city at this time. It was a semi-urban settlement, but with excellent climatic conditions. Mostly, patients suffering from gas poisoning at the front and patients with pulmonary tuberculosis were treated there. Favorable climatic conditions, clean mountain air and good nutrition proved effective in treating such patients. Although her family included small children, Dr. Z.S. Tambiyeva did not leave the hospital for days at a time. A letter that soldier Semyon Paramonov wrote to Z.S. Tambiyeva after being discharged from the hospital reads as follows: “...Dear Mrs. Doctor ... I send you heartfelt greetings, I wish you every happiness and well-being. I also thank you, Mrs. D., for your good relations with the sick and wounded, this alleviates our suffering, which we have to endure in the defense of our homeland and fatherland". ${ }^{10}$

In May 1920, after Soviet rule was established in Kabardino-Balkaria, the local military infirmary was closed, and by order of the medical and sanitary department of the Nalchik District Revolutionary Committee, Z.S. Tambiyeva was appointed head of the women's department of the district (regional) hospi-

\footnotetext{
9 Letters of P.I. Tambiyeva and Z.S. Abdrakhmanova. From the personal archive of S.P. Tambiyeva.

10 Letter of the soldier S.V. Paramonov. From the personal archive of S.P. Tambiyeva. Hereinafter, when reproducing archive materials, the original stylistics are preserved.
}

tal. ${ }^{11}$ One of the first Balkarian doctors, I.M. Abayev (1888-1930), worked with her at the hospital. After the formation of the Kabardino-Balkarian Autonomous Region in 1922, a 100-bed hospital functioned in Nalchik. It had an ambulatory department, a laboratory, a pharmacy, and a dental clinic, with four doctors and 18 nurses (Akhmadov 2014, p. 296).

In connection with P.I. Tambiyev's transfer to work in the Azerbaijan SSR, the family moved to Baku in 1923. A difficult period began in the life of Z.S. Tambiyeva after the arrest of her husband in 1927 (he was arrested on a false charge and in March 1928 he died of fulminant pulmonary tuberculosis in a Rostov-on-Don prison). At first, she hid, working periodically in various medical institutions, and only in March 1936 did she find a permanent job as a gynecologist at Baku City Polyclinic № 3. Ethnic Tatar Amina Yusufovna Batyrshina, who, like Z.S. Tambiyeva, was one of the first Turkestan Muslim doctors, worked there. They were the first female doctors in Baku Governorate. According to the Russian Medical List (for 1905-1907), in 1903 A.Yu. Batyrshina graduated from the Women's Medical Institute in Saint Petersburg, worked in Tashkent and then in 1905 moved to Baku. She received patients in the free city hospital, and actively took part in the work of the Baku Women's Charitable Society (Davletshina 2009). A.Yu. Batyrshina was married to Tashkent's first city doctor - State Counselor Muhamed-Hanafi Alyukovich Batyrshin (Shadmanova 2014), a highly educated doctor who was a pioneer of health care in Turkestan for a quarter of a century and undertook much effort to ensure that his wife received higher medical education (Makhmudov 2015, p. 169).

Dr. Tambiyeva worked in Baku until February 1957. At 76, she retired and moved to Moscow with her eldest daughter, Saadat Tambiyeva (1913-1988), who graduated from the architectural and construction department of an industrial technical school and married a renowned artist, A.G. Smoglovsky. ${ }^{12}$

Throughout her life, Zeynab Sadykovna Tambiyeva maintained a warm relationship with her younger sister. After graduating from the gymnasium with a silver medal, Khadidzha Sadykovna Abdrakhmanova moved to Baku (Tambieva 1984) and became the first teacher of the Baku Muslim Women's Boarding School (Aleksandriinskaya Women's Muslim School), which was founded by oil industry philanthropist Hadzhi Zeynalabdin Tagiyev (Suleymanov 1990). Kh.S. Abdrakhmanova married the well-known doctor and Azerbaijan public figure Hasan bey Aghayev. In Ganja she organized the Women's Charitable Society to help

\footnotetext{
11 Administration of the Central State Archive of the Archival Service of the Kabardin-Balkar Republic. A. R-15. S. 1. F. 2. P. 1.

12 Leila (1915-1932), the youngest daughter of the Tambiyevs, died in her teens.
} 
homeless children, and in Soviet times received fame as a teacher in the republic.

Z.S. Tambiyeva's brother, Izmail Sadykovich Abdrakhmanov, was a military engineer and served in the 6th East-Siberian Sapper Battalion. He fought in World War I and was awarded the Saint George Sword. After being seriously wounded and contused in March 1916, he died in a hospital in Kazan (Tambieva 1984).

Z.S. Tambiyeva died on November 14, 1969. An urn containing her ashes was interred in Baku. She committed half a century of her life to public health care in Uzbekistan, Azerbaijan and Kabardino-Balkaria - all considered her to be their daughter. As a representative of Turkic-speaking peoples, she freely communicated with Azerbaijanis and Balkarians, as well as with

\section{References}

Akhmadov TZ (2014) Istoriya zdravookhraneniya i meditsinskogo obrazovaniya na Severo-Vostochnom Kavkaze (XIX v. - 1940 g.) [The history of health and medical education in the North-East Caucasus (19th century - 1940)]. Rostov-on-Don. 535 p. (In Russ.)

Davletshina LSh (2009) Blagotvoritelnaya deyatelnost musulmanskikh zhenshchin $\mathrm{v}$ obrazovatelnoy sfere [Charitable activities of Muslim women in the educational sphere]. Uchenye zapiski Kazanskogo gosudarstvennogo universiteta. T. 151 [Scientific notes of the Kazan State University. Vol. 151] P. 106-110. (In Russ.)

Dobrosmyslov AI (1912) Tashkent v proshlom i nastoyashchem. Istoricheskiy ocherk [Tashkent in the past and present. Historical essay]. Tashkent: El. tipo-litografiya O.A. Porsha. 557 p. (In Russ.)

Dopolnenie k Rossiyskomu meditsinskomu spisku na 1914 god [Addition to the Russian medical list for 1914] (1915) Petrograd. P. 37. (In Russ.)

Gabdullin IR (2006) Ot sluzhilykh tatar k tatarskomu dvoryanstvu [From service Tatars to Tatar nobility]. Moscow: VINITI. 320 p. (In Russ.)

Istoriya narodov Severnogo Kavkaza (konets XVIII v. - 1917 g.) [History of the peoples of the North Caucasus (the end of the 18th century 1917)] (1988) Ed. by the academician A.L. Narochnitskiy. Moscow: Nauka. P. 518. (In Russ.)

Makhmudov M (1988) Pervye zhenshchiny-vrachi v dorevolyutsionnom Turkestane [The first women-doctors in pre-revolutionary Turkes$\tan$ ]. Sovetskoe zdravookhranenie [Soviet Healthcare] 8: 68-70. (In Russ.)

Makhmudov M (2015) Istoriya meditsiny i zdravookhraneniya Turkestana, Bukhary i Khorezma (1865-1924 gg.) [History of medicine and public health of Turkestan, Bukhara and Khorezm (1865-1924)]. Taraz: Turkistan tulfalary. 277 p. (In Russ.)

Maslov AA, Kardanov AB, Shomakhov AO, Berov ML (2005) Istoriya meditsiny Kabardinskogo okruga: Sobytiya i litsa (1858-1899) [History of Medicine of the Kabardian District: Events and Persons (1858-1899)]. Nalchik: Poligrafservis i T. 300 p. (In Russ.)

Mutieva OS (2016) Kavkazskaya voyna i reformy 60-70-kh godov XIX v., kak faktory integratsii zhenshchin $v$ professionalnuyu meditsinskuyu deyatelnost v Dagestane (XIX v. - nachalo XX v.) [Caucasian war and reforms of the 60s-70s of the 19th century, as factors of the integration of women into professional medical activities in Dagestan (19th
Kabardians through an interpreter. Dr. Tambiyeva devoted her extensive knowledge and vast experience to the noble cause of helping the sick.

\section{Acknowledgment}

The authors are grateful to the following people for their assistance in collecting research materials: Aishat Kuchukovna Shaparova, head of the scientific archive of the Institute of Geography at the Kabardino-Balkar Scientific Center, Russian Academy of Sciences (Nalchik); Andrei Vladimirovich Davidovich, cultural studies researcher, managing teacher, head of the of gymnasium No. 1582 museum (Moscow) and heir to the personal archive of S.P. Tambiyeva. century - beginning of the 20th century)]. Istoricheskaya i sotsialno-obrazovatelnaya mysl [Historical and socio-educational thought] 8(3/1): 55-59. (In Russ.)

Nakhushev KhT (1967) K istorii razvitiya zdravookhraneniya v dorevolyutsionnoy Kabardino-Balkarii [On the history of the development of health care in pre-revolutionary Kabardino-Balkaria]. Uchenye zapiski Kabardino-Balkarskogo NII. T. 35 [Scientific notes of the Kabardino-Balkarian Scientific Research Institute. Vol. 35]. Nalchik. P. 102-103. (In Russ.)

Obzor Syr-Darinskoy oblasti za 1910 god [Overview of the Syr-Darya region in 1910] (1912) Tashkent. P. 172-178. (In Russ.)

Pago Tambiev: K 110-letiyu so dnya rozhdeniya. Sbornik [Pago Tambiev: to the 110th anniversary of the birth. Compilation] (1984) Complied by R.Kh. Khashkhozheva. Nalchik: Elbrus. P. 3-41. (In Russ.)

Psikhomakhova AR (2013) Gendernyy aspekt v tvorchestve i deyatelnosti P.I. Tambieva [The gender aspect in the works and activities of P.I. Tambiev]. Rossiyskaya gendernaya istoriya «yuga» na «zapad»: proshloe opredelyaet nastoyashchee: materialy Shestoy mezhdunarodnoy nauchnoy konferentsii RAIZhI IEA RAN, 3-6 oktyabrya 2013 goda [Russian gender history of the "south" to the "west": the past defines the present: materials of the Sixth International Scientific Conference of the Russian Association of Female History Researchers IEA RAS, October 3-6, 2013]. Nalchik: Izd. Kab.-Balk. un-ta. P. 201-205. (In Russ.)

Rossiyskiy meditsinskiy spisok na 1909 god [Russian medical list for 1909] (1909) Petrograd. P. 479. (In Russ.)

Rossiyskiy meditsinskiy spisok na 1911 god [Russian medical list for 1911] (1911) Saint Petersburg. (In Russ.)

Shadmanova SB (2014) Pervyy gorodskoy vrach Turkestana M.Kh. Batyrshin: Shtrikhi k portretu [The first city doctor of Turkestan M.Kh. Batyrshin: The strokes to the portrait]. Ekho vekov. Kazan [Echo of centuries. Kazan] 1-2: 232-235. (In Russ.)

Shigabdinov RN, Zhukova LI (2002) Tatary [Tatars]. Etnicheskiy atlas Uzbekistana [Ethnic Atlas of Uzbekistan]. Tashkent. P. 202-206. (In Russ.)

Suleymanov M (1990) Dni minuvshie... (Baku v nachale XX v.) [Past days... (Baku at the beginning of the 20th century)]. Transl. by E. Akhundovf. Baku: Azerneshr. 340 p. (In Russ.) 
Tambieva SP (1984) Pago Ismailovich Tambiev v vospominaniyakh docheri [Pago Ismailovich Tambiev in the memories of his daughter]. Pago Tambiev: K 110-letiyu so dnya rozhdeniya [Pago Tambiev: to the 110th anniversary of the birth]. Complied by R.Kh. Khashkhozheva. Nalchik: Elbrus. P. 45-80. (In Russ.)

Vasilyev N (1891) Tashkentskie tatary (statistiko-bytovoy ocherk) [Tashkent Tatars (statistical and household essay)]. Sbornik materialov dlya statistiki Syr-Darinskoy oblasti [Collection of materials for statistics of the Syr-Darya region]. Ed. by I.I. Geyer. Tashkent: Izdanie Syr-Darinskogo Oblastnogo Statisticheskogo komiteta. P. 83-112. (In Russ.)

Zhynisbaev A (2014) Sanzhar Asfendiarov: emiri men Kyzmeti (18891938 zhzh.). Vol. 1. Almaty: Eltanym baspasy. P. 43.

\section{About the authors}

Akhmadov Takhuz Zayndievich - Doctor of Medical Sciences, Professor, The Chechen State University, Grozny, Russia. Email: t.ahmadov@mail.ru

Makhmudov Madrim - Doctor of Historical Sciences, Professor, the Urgench branch of Tashkent Medical Academy, Urgench, Uzbekistan. Email: m.madirim@mail.ru 